University of Nebraska - Lincoln

DigitalCommons@University of Nebraska - Lincoln

1965

Density-Gradient Centrifugation: Non-Ideal Sedimentation and the Interaction of Major and Minor Components

\author{
Myron K. Brakke \\ University of Nebraska-Lincoln \\ J. M. Daly \\ Nebraska Agricultural Experiment Station
}

Follow this and additional works at: https://digitalcommons.unl.edu/plantpathpapers

Part of the Plant Pathology Commons

Brakke, Myron K. and Daly, J. M., "Density-Gradient Centrifugation: Non-Ideal Sedimentation and the Interaction of Major and Minor Components" (1965). Papers in Plant Pathology. 182.

https://digitalcommons.unl.edu/plantpathpapers/182

This Article is brought to you for free and open access by the Plant Pathology Department at DigitalCommons@University of Nebraska - Lincoln. It has been accepted for inclusion in Papers in Plant Pathology by an authorized administrator of DigitalCommons@University of Nebraska - Lincoln. 


\section{Density-Gradient Centrifugation: Non-Ideal Sedimentation and the Interaction of Major and Minor Components}

\footnotetext{
Abstract. $A$ small amount of southern bean mosaic virus was contained in a narrow zone after density-gradient centrifugation, but in a much wider zone after centrifugation with a large amount of a second virus. Zone-spreading of a major component by non-ideal sedimentation in density-gradient centrifugation can cause zone spreading of a minor component that the major component overlaps.

The width of a zone of virus or protein after sucrose density-gradient centrifugation increases as the amount in the zone increases (1). The amount of virus or protein in a zone of a given width is only a few percent of that which would be present if the neg-

ative density-gradient which is due to the virus or protein concentration gradient were equal to the positive density gradient due to the sucrose concentration gradient. Brakke (1) postulated that the increase in zone width as the amount of virus or protein in-
} 
creased was due to non-ideal sedimentation, which became increasingly important as the concentration of virus or protein increased. He further postulated that the mechanism of non-ideal sedimentation was the sedimentation of volume elements containing such excess virus or protein particles as were expected from statistical or fluctuation theory. If this mechanism of non-ideal sedimentation is correct, then the spreading of a component present in high concentration should result in the spreading of a component present in low concentration if the two zones overlap. The present experiments were designed to test this hypothesis.

Radioactive southern bean mosaic virus (SBMV-C ${ }^{14}$ ) (AC No. 17) (2) was prepared by growing infected Bountiful bean plants (Phaseolus vulgaris L.) in an atmosphere containing $\mathrm{C}^{14} \mathrm{O}_{2}$. The SBMV-C ${ }^{14}$ was purified by differential centrifugation after heating the extract from the infected plants for 15 minutes at $50^{\circ} \mathrm{C}$ to denature the normal plant proteins. Tobacco mosaic virus (TMV) (AC No. 2) was purified by the method of Boedtker and Simmons (3). Brome mosaic virus (BMV) (AC No. 66) was purified by differential centrifugation of a frozen extract of diseased barley, Hordeum vulgare L. Moore.

The zone width of SBMV-C ${ }^{14}$ was determined after density-gradient centrifugation of a small amount of SBMV-C ${ }^{14}$ by itself or in the presence

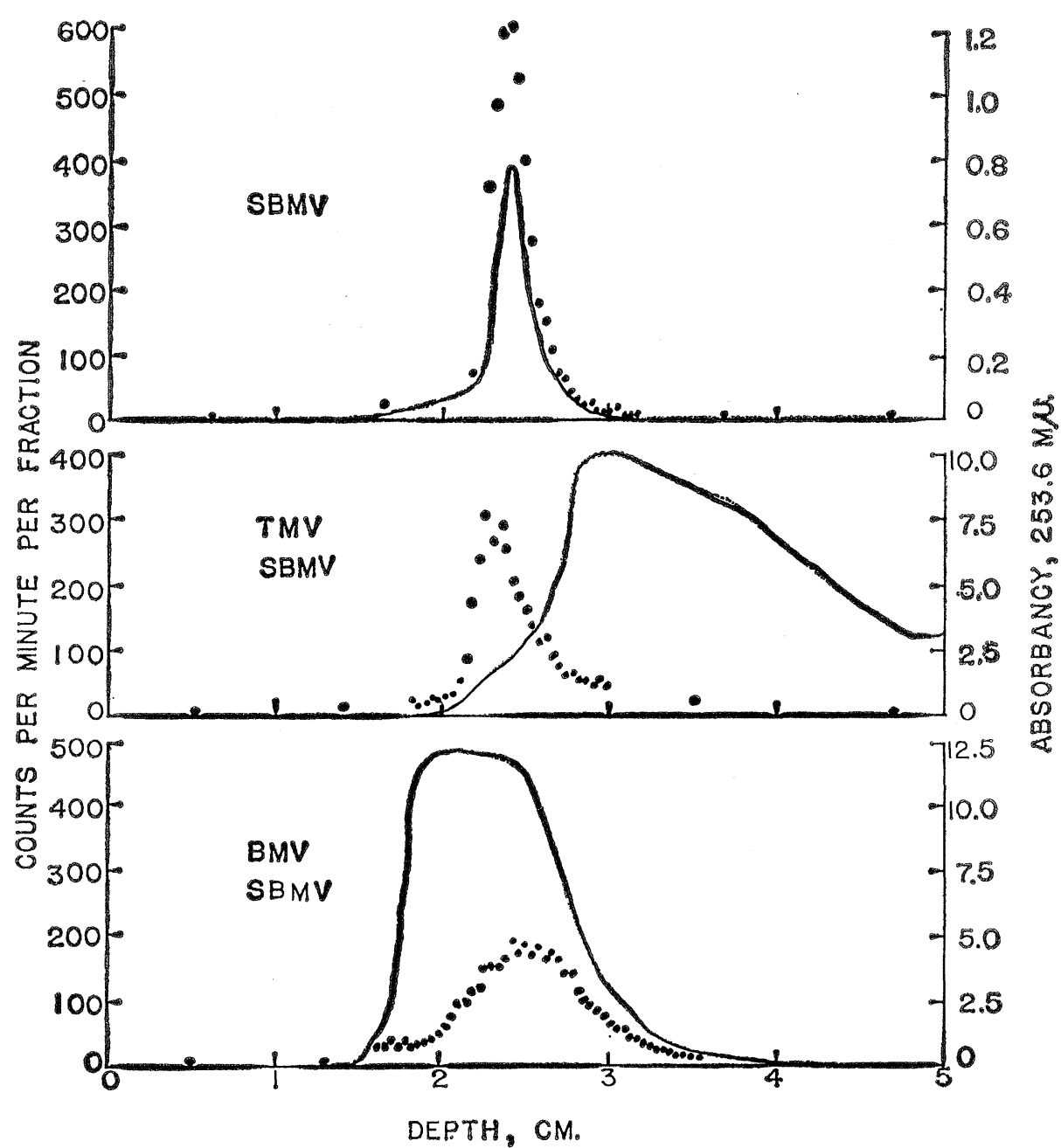

Fig. 1. Absorbancy and radioactivity at different depths after density-gradient centrifugation of $0.3 \mathrm{mg}$ of SBMV-C ${ }^{14}$ by itself, or in the presence of $40 \mathrm{mg}$ of TMV or $20 \mathrm{mg}$ of BMV. A cell with a $2-\mathrm{mm}$ light path was used and absorbancies were multiplied by 5 to give values for a $1-\mathrm{cm}$ light path. The absorbancy in the scanning pattern of SBMV-C ${ }^{14}$ alone was expanded electronically to increase sensitivity. The recovery of radioactivity was 106 percent for the column with SBMV only, 92 percent for SBMV plus TMV, and 94 percent for SBMV plus BMV, after correction for differences in self-absorption between the original sample and samples obtained from the sucrose-gradient column. of a large amount of either BMV or TMV. Gradient columns were prepared by layering $4,7,7$, and $7 \mathrm{ml}$ of $0.01 M$ phosphate buffer, $p \mathrm{H} 6.8$, containing $100,200,300$, and $400 \mathrm{mg}$ of sucrose per milliliter, respectively, in the centrifuge tube. The sucrose column was allowed to stand overnight, $2 \mathrm{ml}$ of virus solution was then floated on it, and it was centrifuged for 3 hours at $23,000 \mathrm{rev} / \mathrm{min}$ at $5^{\circ} \mathrm{C}$ (SW25.1 rotor of the Spinco model L ultracentrifuge) (4).

The centrifuged gradient columns were examined to obtain a recording of absorbancy at $253.6 \mathrm{~m}_{\mu}$ at all depths (ISCO Density-Gradient Fractionator) and consecutive fractions were collected (5), $0.2 \mathrm{ml}$ at depths where preliminary experiments had indicated that most of the radioactivity would be found and larger samples at other depths. These samples were diluted with four volumes of water and three 0.2-ml portions of each were transferred to glass planchets containing lens paper. The weights of material on each planchet were obtained in order to correct for self-absorption.

Because of only slight differences in total amounts of sucrose in the samples, no self-absorption correction was necessary in presenting data (see Fig. 1) for radioactive zones. In order to estimate recovery of viruses on the gradient columns, it was necessary to correct for differences in selfabsorption between the original samples of radioactive virus and each radioactive fraction. High concentrations of sucrose in the samples resulted in erratic counts apparently caused by the geometric effects of sucrose crystallization. The above fourfold dilution eliminated this source of poor reproducibility.

Each gradient column of the experiment whose results are shown in Fig. 1 contained $0.3 \mathrm{mg}(42,000 \mathrm{count} / \mathrm{min})$ of SBMV-C14. In addition, the second column contained $40 \mathrm{mg}$ of TMV and the third, $20 \mathrm{mg}$ of BMV. The BMV has $S_{20}, w$ of $86 S$ (6); SBMV, of $115 \mathrm{~S} \mathrm{(7);} \mathrm{and} \mathrm{TMV,} \mathrm{of} 187 \mathrm{~S}$ (8). These three viruses are well separated by density-gradient centrifugation of small amounts. However, the zones of large amounts of BMV and TMV as used here are wide and overlap the SBMV zone.

Apparently the SBMV-C ${ }^{14}$ zone was much wider in the presence of large amounts of the other two viruses than 
in their absence. Furthermore, the peak concentration of the SMBV $\left(-\mathrm{C}^{14}\right)$ was always lower in the tube in the presence of BMV than when $\operatorname{SBMV}\left(\mathrm{C}^{14}\right)$ was sedimented by itself or with TMV. These data show that non-ideal sedimentation of a major component during density-gradient centrifugation can result in widening of the zone of a minor component that it overlaps and in a different apparent sedimentation rate of the minor component.

Sucrose density-gradient centrifugation is often used to determine the size of particles carrying a certain biological or chemical activity. Results in such experiments are obtained by determining the activity, for example, virus infectivity, enzymatic activity, or a radioactive tracer, at various depths in the column after centrifugation. Viruses and proteins form wide zones at high concentrations (1). Apparently non-ideal sedimentation, which causes the zone spreading, is pronounced at concentrations higher than 2 to 3 $\mathrm{mg} / \mathrm{ml}$ and the sedimenting material spreads until the maximum concentration does not exceed 2 to $3 \mathrm{mg} / \mathrm{ml}$. Our studies show that it is not the concentration of an individual component that determines the amount of non-ideal sedimentation and zone spreading, but rather the total concentration of materials sedimenting together. If this concentration is high, and followed by the determination of enzymatic or other activity, a particle present in low concentration will give neither a true indication of its homogeneity nor an accurate value of its sedimentation rate. For good resolution (1), the amount of sedimenting material should be less than $1 \mathrm{mg}$ for the $2.5-$ by $7.6-\mathrm{cm}$ tube of the SW 25 rotor of the Spinco model L.

MYron K. BRAKKE*

Crops Research Division, U.S.

Agricultural Research Service,

Nebraska Agricultural Experiment

Station, Lincoln

J. M. DALY

Biochemistry and Nutrition Department, Nebraska Agricultural Experiment

Station

\section{References and Notes}

1. M. K. Brakke, Arch. Biochem. Biophys. 107,

2. "Catalog and Registry of the Plant Viruses" (American Type Culture Collection, 2112 M

St., NW, Washington, D.C., ed. 2., 1958).

3. H. Boedtker and N. S. Simmons, J. Am.

Chem. Soc. 80, 2550 (1958).

16 APRIL 1965
4. Mention of a trade named product does not imply endorsement by the U.S. Government. 5. M. K. Brakke, Anal. Biochem. 5, 271 (1963).

5. M. K. Brakke, Anal. Biochem. 5, 271 (1963).

190, 192 (1961).

7. G. L. Miller and W. C. Price, Arch. Biochem. 10, 467 (1946)

8. M. A. Lauffer, J. Am. Chem. Soc. 66, 1195 (1944).

9. Paper No. 1615, Journal Series, Nebraska Agricultural Experiment Station. Based on cooperative investigations by the Crops Research Division, Agricultural Research Service, the U.S. Department of Agriculture and the Nebraska Agricultural Experiment Station. Supported in part by a grant from NSF. We thank Mrs. Alice Estes and Calvin Norman for technical assistance.

19 November 1965 